J. Product. \& Dev., 25(3),323-342 (2020)

\title{
IMPACT OF DIETARY SUPPLEMENTATION WITH NANO AND ORGANIC SELENIUM WITHOUT OR WITH VITAMIN E ON GROWTH PERFORMANCE AND SELENIUM METABOLISM IN GROWING RABBITS
}

\author{
Donia A.S. Abd Allah; M. I. Tawfeek*; Dawlat A. El Kerdawy and A.A. \\ Rashwan \\ Department of Animal and Poultry Production, Faculty of Technology and \\ Development, Zagazig University, Egypt. \\ e.mail:mostawms@hotmail.com,dradam6102017@yahoo.com,
}

\section{ABSTRAC T}

The objective of the present study was to examine the effects of dietary supplementation with two sources of selenium (Se), organic (Org$\mathrm{Se}$ ) and Nano-Se without or with vitamin $E$ (Vit-E) on growth performance and Se metabolism in New Zealand White (NZW) growing rabbits.

In a factorial experimental design (2x3), ninety weaned NZW rabbits of 5 weeks old and with average body weight, $579.5 \pm 5.53 g$ were used in the study for 56 days. Rabbits were randomly distributed into 6 experimental groups and fed the following six diets : (1) control Basal diet without any supplementation, either Vit. E or Se; (2) Basal diet $+250 \mathrm{mg}$ Vit. E/ $\mathrm{kg}$ diet; (3) Basal diet + $0.3 \mathrm{mg}$ Org-Se $/ \mathrm{kg}$ diet; (4) Basal diet + $0.3 \mathrm{mg}$ Org -Se $/ \mathrm{kg}$ diet+ $250 \mathrm{mg}$ Vit. E/ kg diet; (5) Basal diet + $0.3 \mathrm{mg}$ Nano-Se / kg diet; (6) basal diet + $0.3 \mathrm{mg} \mathrm{Nano-Se} / \mathrm{kg}$ diet $+250 \mathrm{mg}$ Vit. E/ $\mathrm{kg}$ diet.

Results of the experiment revealed that live body weight (LBW) and total body gain $(T B G)$ were significantly higher $(P<0.05)$ and feed conversion ratio (FCR) was the best with rabbits fed basal diet plus Nano-Se compared to those fed the control diet or rabbits fed basal diet plus Org-Se. However, with adding Vit. E to the basal diet, the differences in these traits were not significant among the rabbit groups.

Selenium concentrations in kidneys, liver, muscles and blood serum were insignificantly higher in rabbits fed supplemental Nano- Se than in those fed basal diet without any supplementation (control) or those fed 
supplemental Org-Se. However, Se concentration significantly increased $(P<0.05)$ in kidneys and liver in rabbit groups fed supplemental vitamin $E$ and was the highest in rabbits fed supplemental Nano-Se plus Vit. E. Selenium concentration in muscles and blood serum showed statistically similar values among rabbit groups fed diets supplemented with Vit. E.

The economic efficiency (\%) was statistically the same with rabbits fed either Nano-Se plus Vit. E or control diet plus Vit. E, while, it was the lowest with rabbits fed Org-Se compared to the control and other groups.

Conclusively, based on the results of the present experiment and from the economic point of view and to ameliorate the adverse effects of heat stress on growing rabbits during the hot summer conditions in Egypt, it is advisable to supply the basal rabbit diet with Se, either as Nano-Se or Org-Se only without Vit E diet. There are still future studies to determine the effect of Nano Se on human and animal health.

Key words: Nano \& Organic Selenuim Supplementation, Vit. E, Growth Performance, Selenium Metabolism, Rabbits

\section{INTRODUCTION}

Rabbit meat is greatly valued for its high nutritional quality, especially its low amounts of cholesterol, fat and sodium and high content of polyunsaturated fatty acids, potassium, phosphorus and magnesium; for these reasons, it is recommended mainly for children, pregnant women and patients (Cardinali et al., 2015).

Heat stress is the main problem facing rabbits producers in summer in Egypt. The thermo- neutral zone of temperature in rabbits is around $18-21^{\circ} \mathrm{c}$ and when rabbits are exposed to elevated ambient temperature; imbalances are induced in their body temperature. Heat stress stimulated excessive production of oxidative free radicals which in turn adversely affect growth and reproductive performance of rabbits (Okab et al., 2008). In heat - stressed rabbits disturbances occur in feed intake, feed utilization, water metabolism, blood parameters, energy and mineral balances (Okab et al., 2008).

Selenium (Se) is an important dietary micronutrient required for the normal body functions and metabolism of animals (Keen et al., 2004). It 
serving as essential co- factor in the antioxidant enzymes, glutathione peroxidase (GSH - Px), catalase ( CAT) and superoxide dismutase ( SOD) in the body to contract the damage effects of reactive oxygen species (ROS) and numerous peroxides that are known to increase the destructive activity in the organs tissues of rabbits during stress ( Chan and Decker, 1994 and ElKholy et al, 2019b). Dietary selenium is an essential trace element for animal growth, fertility, hormonal and physiological activities, metabolism and immunity. Selenium can be supplemented in the form of organic, inorganic, and nanoparticles. Recent studies showed that nanoparticles of selenium possess comparable efficiency due to its high bioavailability, high catalytic efficiency, strong adsorbing ability and low toxicity compared with other selenium sources (Wang et al., 2009, Liao et al., 2010, Albanese et al., 2012 and Rajendran et al., 2013). Selenium improves the productive performance and antioxidant status of animals, particularly in hot summer environments (Mahima et al., 2012). A lack of selenium in the diet exerts a negative influence on the immune function (Noha Tag-El Din, 2019).

With the use of nanotechnology, nanoparticles can be used as a supplemental source of trace minerals in the diets which have been found to have several novel properties different to those from bulk materials or commercial salts of these minerals (Thulasi et al., 2013 and Mohapatra et al., 2014). Nano sized particles are having higher potential than their conventional sources and therefore reduces the quantity of the required minerals (Sindhura et al., 2014).

Vitamin E (Vit. E) is essential for the body functions as growth, immune response, tissue integrity, reproduction, disease prevention, and antioxidant in activity the biological systems (Ebeid et al., 2013).

Both Se and vitamin E are essential and highly efficient antioxidants which protect rabbits against oxidation of lipid and protein of the organs cell membrane (Koinarski et al, 2005). The combination of vitamin $\mathrm{E}$ and Se at levels above recommended as nutritional requirements could improve humeral immunity (Ziaei et al, 2013) and decrease the adverse effects of heat stress on rabbit performance.

In rabbits, the literature did not explore sufficient information about the role of antioxidants during the heat stress. 
Therefore, the present study was conducted to assess whether dietary supplementation with Se in the form of Org-Se or Nano-Se with or without Vit E has a beneficial effect on heat stressed rabbits. Growth performance traits and selenium metabolism (Se concentration in tissues of liver, kidneys and muscles and blood serum) were used as indices for the study.

\section{MATERIALS AND METHODS}

The experimental work of the present study was conducted at Rabbits

Research Unit, Department of Animal and Poultry Production, Faculty of Technology and Development, Zagazig University, Zagazig, Sharkiya Governorate, Egypt. The experimental period initiated in June 2019 and terminated in August 2019.

The laboratory work was performed at Central Laboratory for Soil, Foods and Feed stuffs (International accredited Laboratory and has ISO 17025 certificate, since 2012), Faculty of Technology and Development, Zagazig University, Zagazig, Egypt.

\section{Animal Housing and management:}

Rabbits were housed in flat deck wire cages $(50 \times 55$ x $40 \mathrm{~cm})$. All cages were equipped with feeders, which were made from galvanized steel sheets, and automatic nipple drinkers. The batteries were located in well ventilated building. The diets were offered to rabbit's ad libitum and drink water was available to rabbits all the time during the experimental period (56 days). The rabbits were kept under the same managerial and hygienic conditions. The ambient temperature $\left(\mathrm{AT},{ }^{\circ} \mathrm{C}\right)$ and relative humidity $(\mathrm{RH}, \%)$ of outdoors and indoors conditions were recorded at $12.00-1.00 \mathrm{~h} \mathrm{pm}$. Indoor, the average ambient temperatures during summer season ranged between 29.6 and $32.6{ }^{\circ} \mathrm{C}$ and relative humidity ranged from 68.5 to $71.0 \%$.

\section{Nano selenium, organic selenium and vitamin $E$ additives}

Nano selenium was purchased from Naqaa Nanotechnology Center, Faisal, Cairo, Egypt. The size of Nano-Se particles was photo measured in the Labs of Petroleum Research Center, Nasr City, Cairo, Egypt. The size of the nano - Se particles ranged from $40-60 \mathrm{~nm}$ as measured by Transmission 
Electron Microscopy (TEM) using JEOL-JEM-1011 Electron Microscope, by dropping the sample suspension in ethanol on a copper $(\mathrm{Cu})$ grid coated with a thin amorphous carbon film (Shah et al., 2010). The concentration of nano-Se in the stock solution was estimated using Atomic Absorption Spectrophotometer (Model Savant AA, GBC) along with hydride generator assembly. Organic selenium and Vitamin E ( $\alpha$ - tocopherol acetate) were purchased from Hay Laboratory Company, Zagazig, Egypt.

\section{Animals, diets and design of the experimental}

The objective of the present study was to examine the effects of dietary supplementation with two sources of selenium (Org-Se and Nano-Se) without or with vitamin $\mathrm{E}$ on growth performance and Se metabolism in NZW growing rabbits.

In a factorial experimental design $(2 \times 3)$, Ninety weaned New Zealand White (NZW) rabbits of 5 weeks old and with average body weight, $579.5 \pm$ $5.53 \mathrm{~g}$ were used in the study for 56 days. Rabbits were randomly distributed into 6 experimental groups and fed the following six diets : (1) control basal diet without any supplementation either Vit. E or Se ; (2) Basal diet +250 mg Vit. E/ kg diet; (3) Basal diet + $0.3 \mathrm{mg}$ Org- Se $/ \mathrm{kg}$ diet; (4) Basal diet + $0.3 \mathrm{mg}$ Org -Se $/ \mathrm{kg}$ diet+ $250 \mathrm{mg}$ Vit. E/ kg diet; (5) Basal diet $+0.3 \mathrm{mg}$ Nano-Se / kg diet; (6) Basal diet $+0.3 \mathrm{mg}$ Nano-Se $/ \mathrm{kg}$ diet $+250 \mathrm{mg}$ Vit. E/ $\mathrm{kg}$ diet. The basal diet was formulated to meet the recommended nutrient requirements of growing rabbits (NCR, 1977).

Chemical analysis of basal diet was done before the start of the experiment. Ingredients and chemical composition of the experimental diets are shown in Table (1). The experimental diets were daily offered to rabbits $a d$ libitum at $09.00 \mathrm{hr}$ AM. The quantity of offered feed and refusal feed were weighed to determine the daily feed intake, while feed conversion ratio (FCR) was determined by dividing the total feed intake by the total weight gain.

Feed conversion ratio (FCR), during the experimental periods was calculated as the following equation:

Feed consumed (g)during a certain period

Body weight gained (g)during the same period 
Table 1: Ingredients and chemical composition of the basal experimental diet.

\begin{tabular}{lc}
\hline Items & \% as fed \\
\hline Ingredients: & \\
Clover hay & 40.50 \\
Wheat bran & 25.00 \\
Yellow corn & 14.00 \\
Soybean meal (44\%) & 11.00 \\
Molasse & 3.00 \\
Molasse & 3.00 \\
Bone meal & 1.75 \\
Calcium carbonate & 0.70 \\
Sodium chloride & 0.55 \\
Vitamins and mineral premix ${ }^{1}$ & 0.35 \\
DL-Methionine & $\underline{0.15}$ \\
\multicolumn{1}{r}{ Total } & $\mathbf{1 0 0}$ \\
\hline
\end{tabular}

\section{Chemical composition (\%):}

Dry matter (DM)

G.E $(\mathrm{kcal} / \mathrm{kg}) * *$

Crude protein $(\mathrm{CP})$

18.17

Crude fibre (CF)

14.15

Ether extract (EE)

4.04

Nitrogen free extract (NFE)

49.50

Ash

Total calcium $(\mathrm{Ca})$

0.88

Total phosphorous (P)

0.52

Lysine****

0.92

Methionine + Cysteine ${ }^{* * *}$

0.64

* Each 3 kilograms of premix contains: Vit. A 12000000 IU, Vit. $D_{3} 1500000$ IU, Vit. E 50 gm, Vit. $\mathrm{K}_{3} 2$ gm, Vit. $\mathrm{B}_{1} 2$ gm, Vit. $\mathrm{B}_{2} 6 \mathrm{gm}$, Vit. $\mathrm{B}_{12} 0.01 \mathrm{gm}$, Chol. Chlod 1200 gm, Biotin 0.2 gm, Niacin 50 gm, Pantothenic acid 20 gm, Folic acid 5 gm, Magnesium $400 \mathrm{gm}$, Copper $5 \mathrm{gm}$, Iodin $0.75 \mathrm{gm}$, Selenium $0.1 \mathrm{gm}$, Iron $75 \mathrm{gm}$, Manganese $30 \mathrm{gm}$, Zinc $70 \mathrm{gm}$.

** It was determined according to Kalogen (1985)

*** It was calculated according to NRC (1977). 


\section{5. Economic efficiency of the experimental diets:}

Economic efficiency (EF) was calculated according to the prevailing prices of the experimental diets and rabbit's meat during year of 2019. Economic Efficiency (\%) was calculated during the experimental periods according to Raya et al. (1991) from the following equation:

$$
\mathrm{EF}(\%)=\frac{\text { Net revenue (L.E) }}{\text { Total feed cost (L. E) }} \times 100
$$

Where, Net revenue $=$ Selling price of weight gain (L.E.) - Total feed cost.

Selling price of weight gain $=$ Average weight gain $(\mathrm{Kg} / \mathrm{head}) *$ Price of one $\mathrm{Kg}$ of Live body weight (L. E.)

Total Feed Cost $=$ Average feed consumption $(\mathrm{Kg} /$ head $)$ x price of one $\mathrm{Kg}$ of feed (L.E.).

\section{Chemical analysis of experimental diets}

The chemical composition of the experimental basal diet was determined in the Central Laboratory for Soil, Foods and Feedstuffs (International Accredited Lab, has ISO 17025 since 2012), Faculty of Technology \& Development, Zagazig University, Zagazig, Egypt.

Chemical analysis of the experimental basal diet was performed according to the International Standard Methods (ISO). Moisture content was according to ISO 6496: 1999, crude protein according to ISO 5983-1:2002, crude ash was according to ISO 5984:2002, crude fat according to the method described in Official Journal of the European Union (EN), 2009, L54/ 37, Volume 52, and crude fiber was according to the method described in Official Journal of the European Union (EN), 2009, L54/ 40, Volume 52.

\section{Samples collection of muscles, liver, kidneys and blood serum for Se} measurements:

At the end of the feeding experiment (at $13^{\text {th }}$ week of age), 18 growing rabbits ( 3 rabbits in each group) were taken for determination of Se concentration in muscles, liver, kidney and blood serum to study Se metabolism inside the body of rabbits. Animals were randomly selected, kept away from feed for 12 hours and weighed, then manually slaughtered by cutting the jugular vein to allow the complete bleeding. 
Blood samples were individually collected from each rabbit into clean and dry non-heparinized tubes. Blood samples were centrifuged at $3000 \mathrm{rpm}$ for 15 minutes to obtain a clear serum and stored at $-20{ }^{\circ} \mathrm{C}$ until determination of selenium concentration in serum. Rabbits were de-skinned, dressed out and the hot carcass was taken for determination of selenium concentration in muscles, liver and kidneys.

Samples of liver, kidneys and muscles were collected (20 gm. of each). Each sample was kept separately in polyethylene bag with identification card showing type of sample, then samples were transported to the laboratory to determine Se concentration in the indicated organs tissues.

\section{Statistical analysis:}

All the data generated in the experiment were statistically analyzed as a factorial design according to Snedecor and Cochran (1982), using the Linear Model Program of SPSS (2014) as the following model :

$$
Y_{i j k}=\mu+S_{i}+V_{j}+S V_{i j}+e_{i j k} \text {. }
$$

Where: $Y_{\mathrm{ijk}}=$ The observation for each dependent variable, $\mu=$ Overall mean, $S_{\mathrm{i}}$ $=$ Forms of selenium effect $(\mathrm{i}=1,2$ and 3$), \mathrm{V}_{\mathrm{j}}=\mathrm{Vit}$. E effect $(\mathrm{J}=1$ and 2$), \mathrm{SV}_{\mathrm{ij}}=$ Interaction effect $(\mathrm{j}=1,2 \ldots$ and 6$), \mathrm{e}_{\mathrm{ijk}}=$ Random error.

The differences among treatments means were compared using Duncan's Multiple-Range Test Procedure (Duncan, 1955).

\section{RESULTS AND DISCUSSION}

\section{1-Effect of dietary supplementation with Nano and Organic -Se without or with Vit. E on Growth performance traits:}

Table (2) show that, at all weeks of study up to the age of marketing (13 weeks), rabbits fed basal diet supplemented with Nano- Se without Vit. E had significantly $(\mathrm{P}<0.05)$ higher live body weight $(\mathrm{LBW})$, total body gain (TBWG) and better feed conversion ratio (FCR) than those fed the control basal diet and those fed Org- Se diet. However, with addition of Vit. E, the differences in these parameters among the rabbit groups during the same periods were not significant, indicating ineffective adding extra Se either as Org-Se or Nano -Se with Vit. E and economically, it is enough to supplement Vit. E only to the basal diet. The obtained results demonstrate that the basal diet 


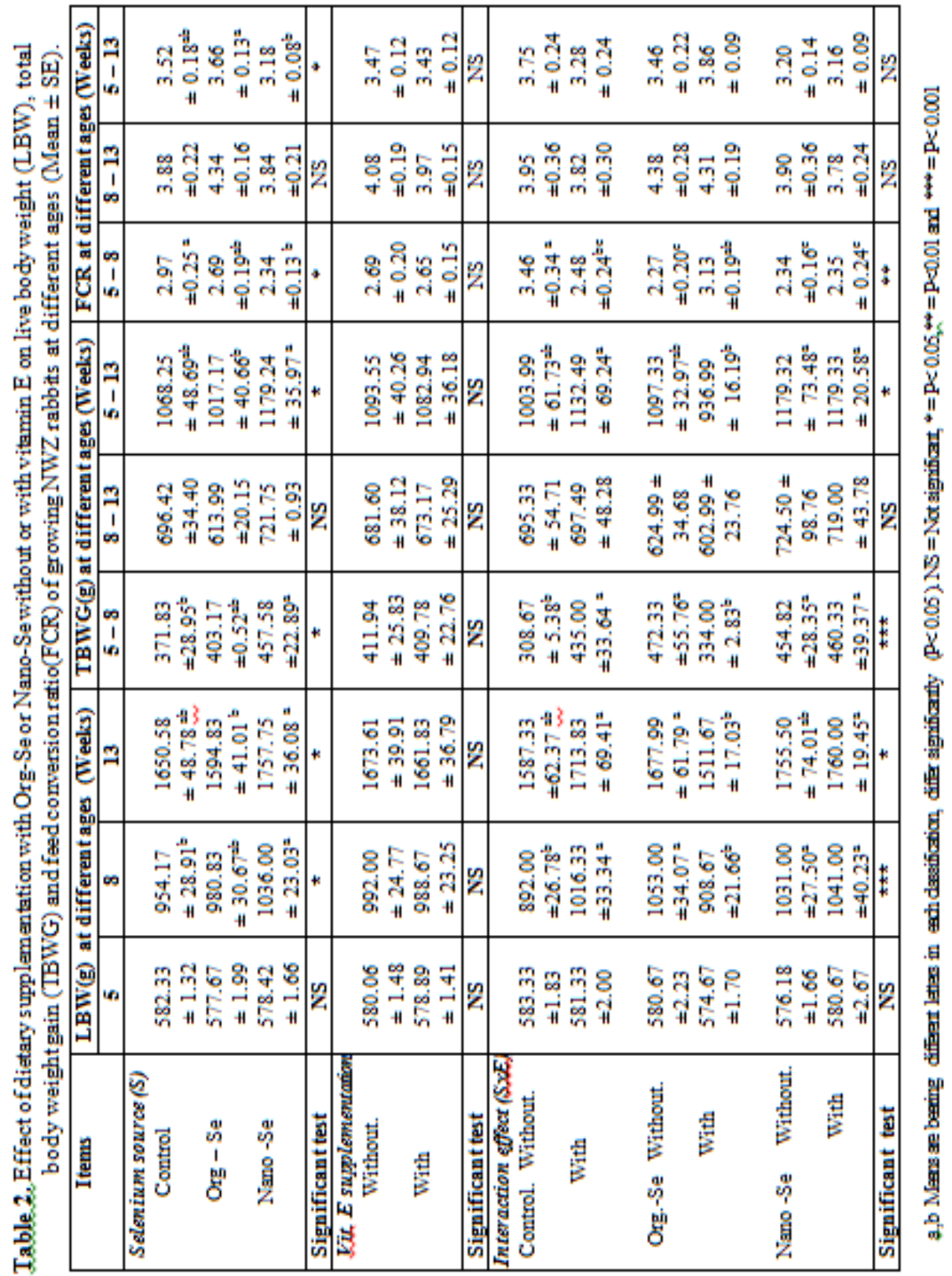


was balanced with Se in the start of experiment due to adding $0.12 \mathrm{mg} \mathrm{Se} / \mathrm{kg}$ diet from the supplemental premix (Table 1). In this concern, Dokoupilova et al., (2007) reported that extra Se supplementation has limited potential to improve the oxidative stability status on rabbit growth performance. Also Jenkins et al. (1970) and Lebas (2004) clarified that the rabbit is more dependent on Vit. $\mathrm{E}$ and less on Se than other mammals in reducing the oxidation load on organs tissues. NRC (1977), Xiccato (1999) and European Commission Regulation (EC, 2003) recommended Se requirements for fattening and does rabbits to be 0.08 , 0.15 and $0.09 \mathrm{mg} / \mathrm{kg}$ diet, respectively.

Zhou and Wang. (2011), El Kholy et al., (2019a), Emara et al., 2019; AbdelWareth et al., 2019; and El-Badry et al., (2019) found that LBW values were significantly the highest and FCR was the best with rabbits received basal diet with Nano-Se at levels between 0.3 and $0.5 \mathrm{mg} / \mathrm{kg}$ diet, followed by rabbits received the same levels of supplemental Org- Se as compared to rabbits fed the basal diet only (control).

Marounek et al.( 2009) and Ebeid et al. (2013) found that no significant effect of supplemental Vit. E on LBW and TWG. On the other hand, McDowell et al. (1996); Eiben et al. (2011) reported that Vit. E supplementation resulted in higher body weight of rabbits. Dalle Zotte and Szendrö (2011) and Rooke et al (2004) interpreted the improvement in body weight by dietary addition of Vit. E to that, Vit. E is essential for normal body functions as growth, immune function enhancement, tissue integrity, and disease prevention, and act as antioxidant in the body biological system.

\section{2-Selenium (Se) concentration in different organs tissues and blood serum of rabbits:}

Table (3) show that the mean values of Se concentration in tissues of kidneys, Liver muscles and blood serum were insignificantly higher in rabbits fed supplemental Nano- Se than in those fed the basal diet without supplementation (Control) and those fed supplemental Org-Se. Adding Vit. E to the basal diet significantly $(\mathrm{P}<0.05)$ increased level of Se in Kidneys and Liver of all rabbit groups fed supplemental Vit. E, while Se concentration in muscles and blood serum was not significantly affected by vitamin E addition to the diet. 
Table 3. Effect of dietary supplementation with Org-Se or Nano-Se without or with vitamin $\mathrm{E}$ on Se concentration $(\mu \mathrm{g} / \mathrm{kg})$ in different organs tissues and blood serum of growing rabbits at 13 weeks of age.

(Mean \pm SE).

\begin{tabular}{|c|c|c|c|c|c|}
\hline & Items & & Se & entration & (kg ) \\
\hline & & Kidneys & Liver & Muscles & Blood serum \\
\hline Selenium s & source $(S)$ & & & & \\
\hline & Control & 3.52 & 4.16 & 2.95 & 3.25 \\
\hline & & \pm 1.35 & \pm .41 & \pm 0.81 & \pm 1.24 \\
\hline & Org $-\mathrm{Se}$ & 3.26 & 6.05 & 2.41 & 3.55 \\
\hline & & \pm 0.60 & \pm 1.12 & \pm .51 & \pm 0.68 \\
\hline & Nano-Se & 6.31 & 7.81 & 3.79 & 5.16 \\
\hline & & \pm 1.86 & \pm .25 & \pm 0.90 & \pm 1.03 \\
\hline Significe & ant test & NS & NS & NS & NS \\
\hline Vit. E supp & plementation & & & & \\
\hline & Without & 2.41 & 4.20 & 2.16 & 3.37 \\
\hline & & \pm 0.74 & \pm .81 & \pm 0.54 & \pm 0.71 \\
\hline & With & 6.31 & 7.81 & 3.94 & 4.60 \\
\hline & & \pm 1.15 & \pm 1.04 & \pm 0.56 & \pm 0.92 \\
\hline Significan & t test & $*$ & $*$ & NS & NS \\
\hline Interaction & $n$ effect $(S x E)$ & & & & \\
\hline Control & Without & 1.05 & 2.42 & 2.32 & 2.14 \\
\hline & & \pm 1.05 & \pm 1.56 & \pm 1.48 & \pm 1.46 \\
\hline & With & 6.00 & 5.90 & 3.58 & 4.36 \\
\hline & & \pm 1.41 & \pm 2.11 & \pm 0.83 & \pm 2.10 \\
\hline Org-Se & Without & 2.39 & 4.02 & 1.67 & 2.79 \\
\hline & & \pm 0.83 & \pm 1.34 & \pm 0.76 & \pm 1.10 \\
\hline & With & 4.12 & 8.08 & 3.14 & 4.31 \\
\hline & & \pm 0.59 & \pm 0.62 & \pm 0.42 & \pm 0.73 \\
\hline Nano -Se & Without & 3.79 & 6.18 & 2.50 & 5.20 \\
\hline & & \pm 1.70 & \pm 0.32 & \pm 0.73 & \pm 0.49 \\
\hline & With & 8.83 & 9.44 & 5.09 & 5.12 \\
\hline & & \pm 2.84 & \pm 2.26 & \pm 1.36 & \pm 2.26 \\
\hline Significan & t test & NS & NS & NS & NS \\
\hline
\end{tabular}

a, b Means are bearing different Letters in each classification, differ significantly $(\mathrm{P}<0.05)$. NS = Not Significant,$\quad *=\mathrm{P}<0.05$.

Note: 3 Mean of samples in each group. 
In this regard, Ceballos and Wittwer (1996) found that Se basses from the blood into the tissues and is mainly concentrated as proteins (mainly as selenocysteine and GSH- PX) in kidneys, liver, pancreas and spleen and to small extent in muscle, bones and brain. Georgievskii (1982) reported that the main routes of Se excretion are in faeces (as insoluble selenide), urine (as trimethyle selenium) and few percentages (2-3\% of uptake) through the lunges. The author added that under normal conditions, monogastric animals retain about 18-20\% and ruminants retain 20-25\%. These results were disagreement with the results reported by Dokoupilova et al. (2007); Wang and Xu. (2008); Marounek et al. (2009); Liu et al. (2011); Ebeid et al. (2013); Amer et al. (2018) and El-Kholy et al. (2019a) who found that muscle- Se concentration was significantly $(\mathrm{P}<0.05)$ increased in rabbits fed diet supplemented with $0.3 \mathrm{mg} \mathrm{Se} / \mathrm{kg}$ diet compared with those fed un- supplemented Se diet (control). These results are also disagreement with the results obtained by Ebeid et al.(2013) and El-Kholy et al.(2019a) who observed that the concentration of $\mathrm{Se}(\mu \mathrm{g} / \mathrm{kg})$ in the hind leg significantly increased $(\mathrm{P}<0.05)$ in rabbits fed diet supplemented with Org- Se plus Vit. E compared with those fed diet with Vit. E only. Belma Turan et al. (1997) showed that plasma Se level decreased in the group of rabbits fed supplemental Se plus Vit. E compared with those fed un-supplemented diet (control).

\section{Economic efficiency (\%):}

Table 4 show that economic efficiency (EE) for raising the growing rabbits up to the age of marketing (13 weeks age) was the highest with rabbits increased fed basal diet plus Nano- Se, followed by those fed Org- Se compared to EE of control rabbits. Similar results were obtained by El Badry et al.(2019) who reported that the highest economic efficiency was recorded with rabbits fed supplemental Nano Se, followed by rabbits fed supplemental org-Se compared to the control group. However, the EE was statistically the same with rabbits fed either Nano- Se plus Vit. E or basal diet plus Vit. E only. The economic efficiency was the lowest with rabbits fed Org- Se plus Vit. E compared to the other groups. The obtained results show that it is not beneficial to supplement extra Se either as Nano- Se or Org- Se to the basal diet because the latter is balanced with Se (Table 1). The results obtained of growth performance support these findings (Table 2). 
Table 4. Effect of dietary supplementation with Org-Se or Nano-Se without or with vitamin $\mathrm{E}$ on economic efficiency (EE) at different ages of NWZ growing rabbits.

\begin{tabular}{|c|c|c|c|}
\hline \multirow{2}{*}{ Items } & \multicolumn{3}{|c|}{ EE $(\%)$ at at different ages } \\
\hline & $(5-8)$ & $(8-13)$ & $(5-13)$ \\
\hline \multicolumn{4}{|l|}{ Selenium sources } \\
\hline Control & 210.63 & 136.16 & 161.51 \\
\hline Org- Se & 235.53 & 109.79 & 148.48 \\
\hline Nano- Se & 280.51 & 132.52 & 180.68 \\
\hline \multicolumn{4}{|l|}{ Supplementation Vit. E } \\
\hline Without & 250.51 & 130.98 & 171.50 \\
\hline With & 229.80 & 120.33 & 154.83 \\
\hline \multicolumn{4}{|c|}{ Interaction (Se \& Vit. E) } \\
\hline $\begin{array}{ll}\text { Control } & \text { Without } \\
& \text { With }\end{array}$ & $\begin{array}{l}175.25 \\
256.44\end{array}$ & $\begin{array}{l}141.11 \\
131.41\end{array}$ & $\begin{array}{l}153.97 \\
169.51\end{array}$ \\
\hline $\begin{array}{l}\text { Without } \\
\text { With }\end{array}$ & $\begin{array}{l}\mathbf{3 1 6 . 8 7} \\
180.75\end{array}$ & $\begin{array}{l}116.05 \\
103.88\end{array}$ & $\begin{array}{l}\mathbf{1 7 3 . 5 0} \\
127.65\end{array}$ \\
\hline $\begin{array}{ll}\text { Nano Se } & \begin{array}{l}\text { Without } \\
\text { With }\end{array}\end{array}$ & $\begin{array}{l}295.69 \\
266.44\end{array}$ & $\begin{array}{l}\mathbf{1 3 7 . 4 2} \\
127.82\end{array}$ & $\begin{array}{l}\mathbf{1 8 9 . 3 5} \\
172.51\end{array}$ \\
\hline
\end{tabular}

Note: Selling price of live body weight for rabbits $=40 \mathrm{LE} / \mathrm{Kg}$; Price of diet without additive $=\underline{4.2}$ $\mathrm{LE} / \mathrm{Kg}$; Price of diet with vitamin $\mathrm{E}=\underline{4.35} \mathrm{LE} / \mathrm{Kg}$;. Price of diet with organic selenium $=\underline{4.23}$ $\mathrm{LE} / \mathrm{Kg}$; Price of diet with organic selenium \& vitamin $\mathrm{E}=4.55 \mathrm{LE} / \mathrm{Kg} ; \mathrm{P}$ price of diet with Nano selenium $=\underline{4.32} \mathrm{LE} / \mathrm{Kg}$; Price of diet with Nano selenium \& vitamin $\mathrm{E}=\underline{4.65} \mathrm{LE} / \mathrm{Kg}$.

From the economic point of view, it is recommended to supplement only $250 \mathrm{mg} / \mathrm{kg}$ Vit. E to the basal diet to countermeasure the adverse effects of heat stress on growth performance of growing rabbits during the hot summer condition in Egypt. Addition of extra Se at level $0.3 \mathrm{mg} / \mathrm{kg}$ diet to the basal diet as Nano- Se or Org- Se, economically is not beneficial. In this regard Robledo et al. (1999) and Lebas (2004) stated that although the commercial premixes without selenium supplementation have been marketed for many years in Europe without any evidence of impaired productivity in does or growing fattening rabbits, it is advisable to include a small amount of supplemental selenium $(0.05 \mathrm{mg} / \mathrm{kg}$ diet $)$ in the feed of rabbits to increase their immunity response against the adverse effects of heat stress. 
Conclusively, based on the results of the present experiment and from the economic point of view and to ameliorate the adverse effects of heat stress on growing rabbits during the hot summer conditions in Egypt, it is advisable to supply the basal rabbit diet with Se, either as Nano- Se or Org-Se only without Vit E diet. There are still future studies to determine the effect of Nano Se on human and animal health.

\section{REFERENCES}

Abdel-Wareth, A.A.; A.E. Ahmed; H.A. Hassan; M.S. Abd El-Sadek; A.A. Ghazalah and J. Lohakare (2019). Nutritional impact of nano-selenium, garlic oil, and their combination on growth and reproductive performance of male Californian rabbits. Animal Feed Science and Technology, 249, 37-45

Albanese, A.; PS. Tang and WC. Chan (2012). The effect of nanoparticle size, shape, and surface chemistry on biological systems. Annual Review of Biomedical Engineering, 14:1-6.

Amer, S. A., A. E. Omar and M. E. Abd El-Hack (2018) Effects of seleniumand chromium-enriched diets on growth performance, lipid profile, and mineral concentration in different tissues of growing rabbits. Biological Trace Element Research, 12011-12018.

Belma, T.; Z. Nezahat; K Emine.; S. Yclksel; and A Nuri. (1997). Dietary Selenium- and Vitamin E Induced Alterations in Some Rabbit Tissues. Biological Trace Element Research, Article number: 237 Sept. (1997), Vol. 58, https://doi.org/10.1007/BF02917474.

Cardinali, R. A.; M. B. Cullere; A. CN. DalBosco; C. D. Mugnai, S. C.Ruggeri; S. D. Mattioli; C. C. Castellini; M. E. Trabalza Marinucci; and A. Dalle Zotte. (2015). Oregano, rosemary and vitamin E dietary supplementation in growing rabbits: Effect on growth performance, carcass traits, bone development and meat chemical composition. Livestock Science, 175:83-89.

Ceballos, M.A. and M.F.G. Wittwer (1996). Selenium metabolism in ruminants. Archives de Medicina Veterinaria, 28(2): 5-15

Chan K. and E. Decker (1994). Endogenous skeletal muscle antioxidants. Critical Reviews in Food Sci. and Nutr., 34, 403-426. 
Dalle Zotte, A., Zs Szendrö, (2011). The role of rabbit meat as functional food, A: Review. Meat Sci., 88: 319-331.

Dokoupilová, A; M.Marounek,; V.Skřivanová, and P. Březina, (2007). Selenium content in tissues and meat quality in rabbits fed selenium yeast. Czech J. Anim. Sci., 52: 165-169.

Duncan, D. B.(1955). Multiple Range Tests and Multiple F. Tests. Biometrics,11:1-42.

Ebeid, T. A.; H.S. Zeweil; W. Basyony; M. Dosoky and H. Badry, (2013). Fortification of rabbits diets with vitamin E or Selenium affects growth performance, lipid peroxidation, oxidative status and immune response in growing rabbits. Livestock Science, 155: 323-331

Eiben, Cs.; B. Végi,; Gy.Virág,; K.Gódor- Surmann,; K.Kustos,; A Maró,.; M. Odermatt,; E. Zsédely,; T. Tóth,; J.Schmidt, and H.Fébel, (2011). Effect of level and source of vitamin E addition of a diet enriched with sunflower and linseed oils on growth and slaughter traits of rabbits. Livest. Sci. 139: 196-205.

El-Badry, A.S.O.; M. H.Mahrousa; G.A.G. Mosalm; S. A.Ekram and T.A. ElAasar. (2019). Influence of ingestion of nano-selenium on growth performance, antioxidative and mutagenicity status in somatic cells of New Zealand White rabbits. Egyptian J. of Rabbit Sci., 29 (1): 1-21.

El-Kholy K.H; H. T. Tag El-Deen; A. Abd El-Latif and A. Mekawy (2019a). Effect of Dietary Addition of two Selenium Sources on Productive Efficiency and Selenium Content in Tissues in Growing Rabbits. J. Sus. Agric. Sci., Vol. 45, No. 1, pp. 27- 36 .

El-Kholy, K.H.; H.T. Tag El-Deen; A.I. Abd-El-Lateif and A.I Mekaouy (2019b). Effects of Dietary Selenium Sources on Metabolic, Enzymatic and Immunoglobulin Serum Profiles in Growing Rabbits. Pakistan Journal of Nutrition. ISSN 1680-5194, DOI: 10.3923/pjn.2019.430-436.

Emara, S.S., H.M. El-Zaher, M. I. Michael and S. Y. Eid (2019). Comparative Effects of Nano-Selenium and Sodium Selenite Supplementation on Blood Biochemical Changes in Relation to Growth Performance of Growing New Zealand White Rabbits. Arab J. Nucl. Sci. Appl., Vol. 52(4): 1-14.

Georgievskii, V.I. (1982). The Physiological Role of Microelements: Mineral Nutrition of Animals. Butterworth's London, Poston Sydney, Duran Wellington Toronto, pp.215. 
Jenkins, K.J.; M. Hidiroglow; R.R. Mackay and J.G. Proulx (1970). Influence of selenium and linoleic acid on the development of nutritional muscular dystrophy in beef calves, lambs and rabbits. Canadian Journal of Comparative Medicine, 50: 137-146.

Kalogen, U.A. (1985). Rabbits Nutrition (In Russian). Agropromozdat Publishing, Moscow, Russia..

Keen, CL.; JY. Uriu-Adams; JL. Ensuma and ME. Gershwin (2004). Trace Elements/Minerals And Immunity. Handbook of Nutrition and Immunity. Totowa, NJ, USA: Humana Press, pp.117-140.

Koinarski, V.; N. Georgiera; V. Gadiera and P. Petkov (2005). Antioxidant status of broiler chickens infected with Eimeria acervulina. Revue Med. Vet., 156: 498- 502

Lebas, F. (2004). Reflections on rabbit nutrition with special emphasis on feed ingredients utilization. In: Becerril, C.M. and Pro, A. (eds). Proceedings of the 8th World Rabbit Congress, Puebla. Colegio de Postgraduados, Montecillo, Spain, pp. 686-736.

Liao, C.D., Hung, W.L., Jan,K.C., Yeh, A.I., Ho, C.T. and Hwang, L.S. (2010). Nano/sub-microsizedlignan glycosides from sesame meal exhibit higher transport and absorption efficiency in Caco-2 cell monolayer. Food Chemistry, 119:896-902.

Liu, S. M., H. X. Sun; C. Jose; , A. Murray, , Z. H.Sun, , J. R.Briegel; R Jacob, and Z. L.Tan, (2011). Phenotypic blood glutathione concentration and selenium supplementation interactions on meat colour stability and fatty acid concentrations in Merino lambs. Meat Sci. 87: 130-139.

Mahima, A.K., Amit, K., Anu, R., Vinod, K., Debashis, R., 2012. Inorganic versus organic selenium supplementation : A review. Pak. J. Biol. Sci. 15 (9): 418-425.

Marounek, M.; A. Dokoupilová, .; Z. Volek, and I. Hoza (2009). Quality of meat and selenium content in tissues of rabbits fed diets supplemented with sodium selenite, selenized yeast and selenized algae. World Rabbit Sci. 17: 207-212.

McDowell, L. R.; , S. N. Williams; N. Hidiroglou; , C. A. Njeru; Hill, G. M.; L. Ochoa, and Wilkinson, N. S. (1996). Vitamin E supplementation for the ruminant. Anim. Feed Sci. Technol. 60: 273-296. 
Mohapatra P.; R. K Swain.; S. K. Mishra; T. Behera; P. Swain; S.S Mishra.; N. C. Behura; S. C. Sabat; K. Sethy; K. Dhama and P.Jayasankar (2014). Effects of dietary nano-selenium on tissue selenium deposition, antioxidant status and immune functions in layer chicks. Int. J. Pharmacol., 10: $160-167$.

Noha T.H. Tag-El Din (2019). Effects of dietary nano-zinc and nano-selenium addition on productive and physiological performance of growing rabbits at fattening period. Egyptian J. Nutrition and Feeds, 22(1): 79-89.

NRC (1977). Nutrient Requirement of Domestic Animal. Nutrient Requirement of Rabbits. $2^{\text {nd }}$ Edition National Academy of Science Washington D.C., USA.

Official Journal of the European Union (EN), 2009, L54/ 37, Volume 52.

Official Journal of the European Union (EN), 2009, L54/ 40, Volume 52.

Okab A.B.; S.G. El-Banna and A.A. Koriem (2008). Influence of Environmental Temperatures on Some Physiological and Biochemical Parameters of Male New-Zealand Rabbits. Slovak J. Anim. Sci.. 41: 12-19

Rajendran, D.; A. Thulasi; S. Jash; S. Selvaraju and SB. Rao (2013). Synthesis and application of nano minerals in livestock industry. Animal Nutrition and Reproductive Physiology (Recent Concepts). Satish Serial Publishing House, Delhi, 517-530.

Raya, A.H.; , A.M. Abbas and M.A. Hussein, (1991). Comparative studies on the efficiency of some plant protein source to replace soybean meal in rations for broiler chicks. 1. Performance of chicks and economic efficiency. J. Agric. Sci, Mansoura Univ. 16 (11):2514-2527.

Robledo, D., Garcia, M., Gracia, M.I. and Mateos, G.G. (1999). Estudio comparativo de la composicion de los correctores minero-vitaminicos espanoles en cunicultura. ITEA, 20, 478-480.

Rooke, J. A., Robinson, J. J., Arthur, J. R., (2004). Effects of vitamin E and selenium on the performance and immune status of ewes and lambs, a review. J. Agric. Sci., 142: 253-262.

Shah, C.P., Singh, K.K., Kumar, M. and Bajaj, P.N. (2010) Vinyl monomersinduced synthesis of polyvinyl alcohol-stabilized selenium nanoparticles. Mater. Res. Bull., 45: 56-62. 
Sindhura, KS.; TN. Prasad; PP. Selvam and OM. Hussain (2014). Synthesis, characterization and evaluation of effect of phytogenic zinc nanoparticles on soil exo-enzymes. Applied Nanoscience, 4 (7):819-827.

Snedecor, G.W. and Cochran, W.G. (1982). Statistical Methods. $6^{\text {th }}$ edition, Towa State University Press, Ames, Iowa, USA.

SPSS (2014). Statistical Package for Social Science, Version 14, Chicago, USA.

Thulasi, A.; D. Rajendran; S. Jash; S. Selvaraju; V. Lyju Jose and S. Velusamy (2013). Nanobiotechnology in animal nutrition. In: Sampath, KT, Ghosh J, Bhatta R, editors. Satish Serial Publishing House, New Delhi, 499515 .

Wang, R.R.; X.J. Pan; and Z.Q. Peng; (2009) Effects of heat exposure on muscle oxidation and protein functionalities of pectoralis majors in broilers. Poultry Science 88: 1078-1084.

Wang, Y. B; and B. H. Xu; (2008). Effect of different selenium source (sodium selenite and selenium yeast) on broiler chickens. Anim. Feed Sci. Technol. 144, 306-314.

Xiccato, G. (1999). Feeding And Meat Quality In Rabbits: A review. World Rabbit Science, 7: 75-86.

Zhou X.; and Y. Wang (2011). Influence of dietary nano elemental selenium on growth performance, tissue selenium distribution, meat quality, and glutathione peroxidase activity in Guangxi Yellow chicken. Poult. Sci., 90: 680-686.

Ziaei, N.; N. Moradikeor and E. Esfandiar Pour (2013). The effect of different levels of vitamin $\mathrm{E}$ and organic Selenium on performance and immune response of laying hens. Afr. J. Biotechnol., 12: 3884-3890. 


\section{تأثير إضافة السيلينيوم النانو والعضوي بلون أو مع إضافة فيتامين على اداء النمو والتمثيل الغذائي للسيلينيوم في الأرانب النيوزئيو التيلندي البيضاء النامية.}

دنيا أحمد سيد عبدالله - مصطفي ابراهيم توفيق - دولت عبد العزيز الكرداوي -

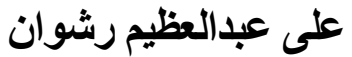
قسم الانتاج الحيو انى و الداجنى ـ كلية التكنولوجيا و التنمية ـ جامعة الزقازيقـ مصر

هدفت الدراسة الحاليةمعرفة تأثير إضافة النانو سيلينيوم و السيلينيوم العضوي بدون ألئيو أو مع فيتامين E على أداء النمو وتمثيل السيلينيوم في الأرانب النامية.

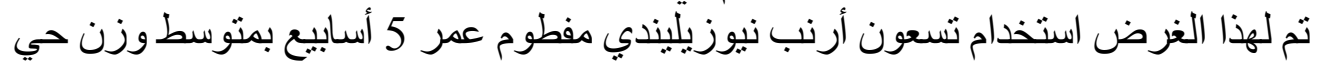

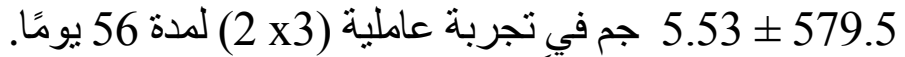

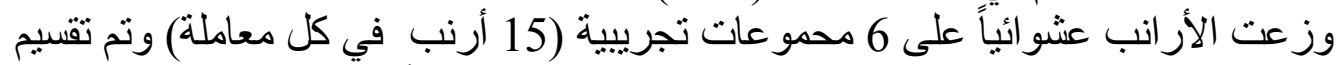

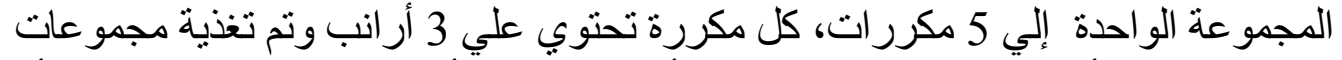

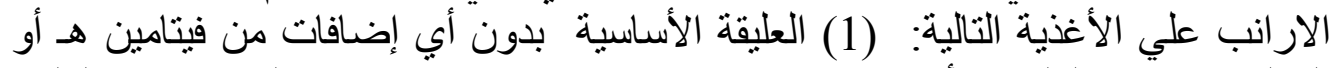

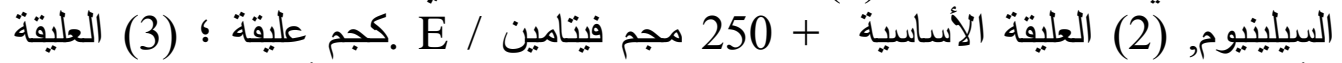

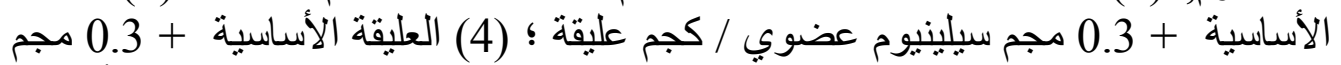

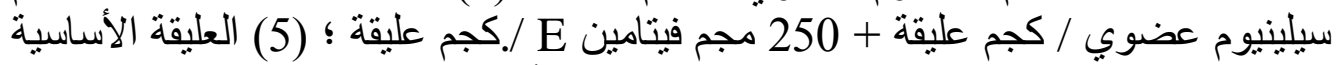

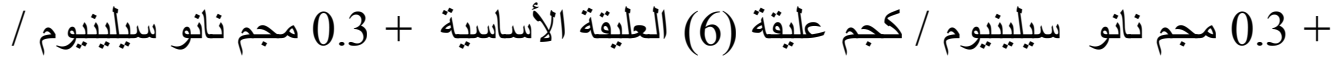

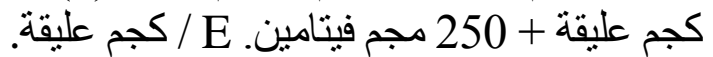
يمكن تلخيص نتائج التجربة في الأتي:

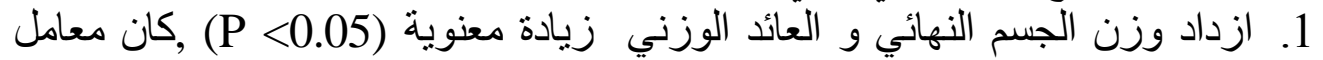

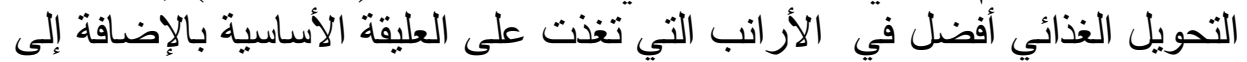

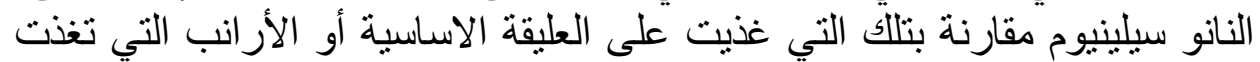

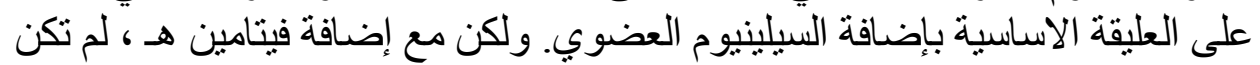

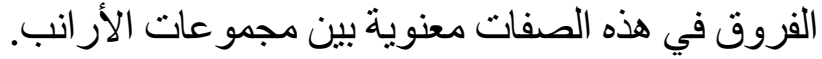

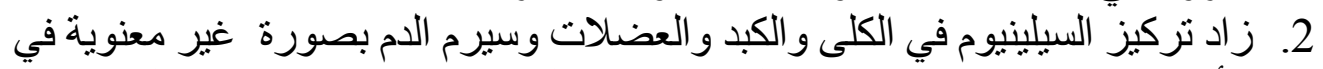
الأرانب التي غذيت على العليقة المضاف إليها النانو سيلينيوم مقارنة بتلك التي غذيت فيتي 
على العليقة الأساسية دون أي إضافات (كنترول) أو الار انب التي غذيت علي العليقة

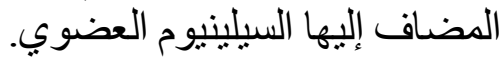

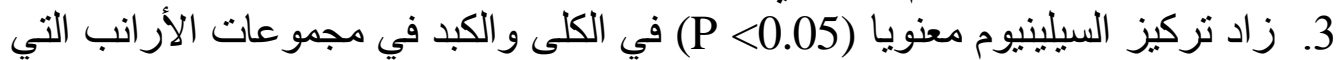

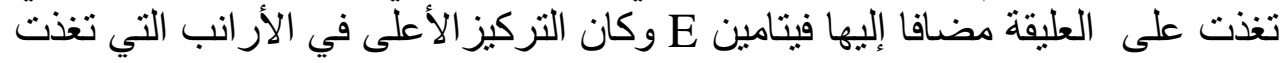

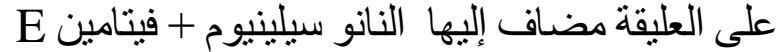

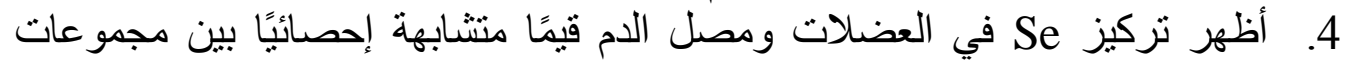

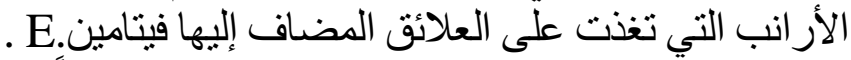

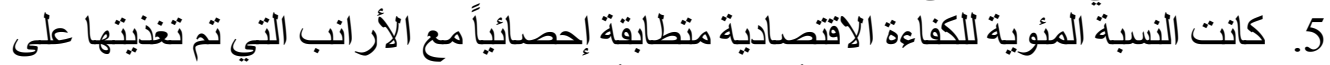

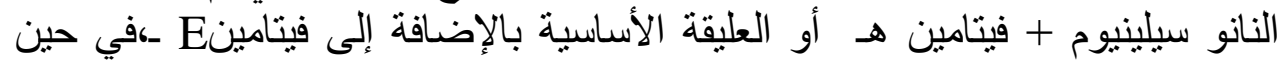
الخفضت الكفاءة الاقتصادية عند تغذية الأرانب علي العليقة الأساسية فقط مقارنة

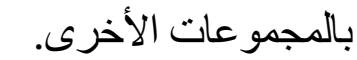
التوصية: بناءً على نتائج التجربة الحالية ومن وجهة النظر الاقتصادية وللتخفيف من الآثار

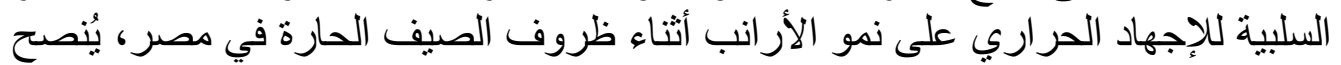

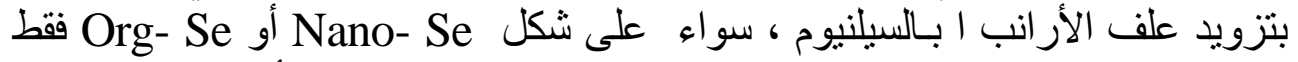

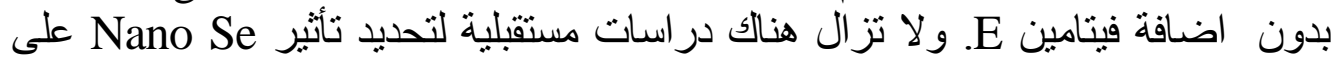

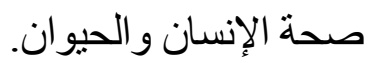

